\title{
Implementation of Value Added Tax in Nepal
}

\section{- Reem Prasad Humagai ${ }^{*}$}

\begin{abstract}
s
In the empirical study, the analysis has been done about VAT on the basis of information collected from experts, tax officials, businessmen and consumers. The tool basically used is questionnaire. The questions were asked to 60 different individuals related to this field. Empirical as well as theoretical analysis showed that VAT is superior to other types of Sales tax. Not only that, most of the respondents have also viewed in VAT as best instrument for research mobilization, bright future and discouraging illegal business. Similarly, most of the respondents (Tax Experts \& Officials), argued that billing problem, open boarder, administrative incapability as hunting problem. They also discussed about legal provisions, choice between single or multi rated VAT, behavior of tax personnel, rate of VAT, need of public awareness programs etc.
\end{abstract}

Keywords: Goods and services tax, multi-stage tax, modified value added tax, value added tax (VAT)

\section{Introduction}

VAT is the important tax innovation on the second half of the twentieth century. VAT is a scientific tax system which was first introduced in 1954 in France. VAT has been spreading all over the world. Since, late 1960s and now this tax has become one of the main stays of the tax system in over the world 130 countries. In south Asia Pakistan adopted VAT in 1990 and Bangladesh and Sri Lanka have since 1991 and 1995 respectively. Also in India, VAT is adopted in restricted form called; Modified Value Added Tax (MOD VAT) with effect from 1986. The MOD VAT is limited in scope it covers only half of the revenue collected. An India has just adopted full VAT since the year 1999 (Kandel, 2009).

The concept of VAT in Nepal was introduced in early 1990s. Nepal government indicated its intention to introduce VAT in the eight plans subsequently the finance minister declared to introduce a two-tier sales tax system to make the base of implementation of VAT from the fiscal year 1992/1993. The parliament of Nepal enacted "VAT Act, 1995(2052)" in 1995 subsequently VAT registration was made in delayed due to political instability and strong opposition from the business community (Adhikari, 2007). VAT with single rate of $10 \%$

* Mr. Humagai is a Faculty Member of the Department of Economics, Patan Multiple Campus, TU, Nepal 
was fully implemented with effectively from 16 Nov, 1997. It has replaced sales tax, hotel tax, contract tax and entertainment tax. It has designed to collect same revenue as the four taxes it replaced. VAT is a new tax system for Nepal. VAT has been justified in the light of government fiscal imbalances and need for extra revenue mobilization through an efficient tax system. The government of Nepal has increased VAT to 13\% with effect from Magh1, 2061.

VAT is indirect tax. It is an improved and modified form of sales tax. It is levied on value added of goods and services at each stage in the process of production and distribution chain. These stages can be import, manufacturing, wholesale and retail. Value added for a firm is sales value minus all expenditure on goods and services purchased from other firms. The value added can be obtained by adding payments to factors of production i.e. wages, salaries, rent, interest and profits. This value added is the base of VAT. Although VAT is eventually borne by the final consumer. It is collected at each stage of production and distribution chain. In the VAT system the registered dealers obtain tax credit for the tax paid directly by them on goods purchased by them for manufacture of sale (Bhattarai \& Koirala, 2006). VAT is the recent innovation in the field of taxation in Nepal. Despite all the constraints and obstructions from the business communities, VAT was introduced with the objectives of increasing revenue mobilization by broadening the tax base, and of instilling neutrality, efficiency, fairness, and transparency in tax administration. It was launched in place of the four different taxes namely Sales Tax, Contract Tax, Entertainment Tax and Hotel Tax. In Nepal consumption type VAT is being implemented.

\section{Statement of Problems}

VAT plays great role in the revenue mobilization in Nepal. The reason behind VAT system, it makes transparency in all kinds of transaction, helps to make the wide area of tax and discourages tax evasion. So it is needless to say that VAT is the most important sources of the government revenue. VAT was implemented after several preparations program such as publicity, campaign, workshop, training advertisements, publication of articles discussion on radio and television, commenced various booklets and other materials were published. In this process only the positive aspects of VAT were discussed and publicized. The negative aspects were not taken into consideration. So that shortcoming that can enter on the process of VAT implementation could not be discussed. VAT has some difficulties in the administrative aspect as well. Only a good tax system is not sufficient to make the revenue collection procedure effective, effective implementation of the system is also necessary. VAT is a scientific, simple and very good tax system. However, there are so many problems regarding implementation of VAT system. It has been about 20 years of VAT implementation in Nepal, but there are so many problems in its effective implementation. 
Implementation of VAT was not easy in the initial days. It was a matter of great debate. Even after the enactment of law, there were a lot of constraints and difficulties in introducing and implementing VAT in Nepal. A large number of entrepreneurs, traders and business communities were against VAT system. The initial two year of VAT implementation was very turbulent. Now it has become familiar and VAT is currently well received by the consumers as well as business and industrial communities of Nepal. This is account based tax system that leads to transparency and accountability on the both part of tax payers and tax collectors. The present situation of VAT showed the need for understanding and commitment at the general taxpayer level, political level, and motivated tax administration, serious study of the negative aspects of the new tax system and honest and earnest attempts and environment to tackle the problem in order to make any tax system revenue productive. It seems its right time to make an assessment the VAT by identifying its problems that has been arisen are going to be arises in the due process of effective implementation and prospects of revenue mobilization through VAT in the country. How better is the system, if proper implementation is lacking there will be no benefit of the system? At present, the issues have become the effective implementation of VAT system in Nepal. It is not matter that VAT should be removing but the implementation aspect should be managed. VAT regime is extremely challenging in a burgeoning economy like Nepal. Resistance from the business community, ignorance of general people, lack of full support and commitments from the politicians and government officials forced the authority responsible for implementing VAT to make compromises on various aspects of VAT which has weakened the process of its implementation right from the beginning. The attitude of businessmen and tax administration also appear hostile to the effective implementation of VAT in Nepal. It is the most advance and scientific system of tax. Therefore, Effective implementation of VAT system is necessary in Nepal.

Nepal is a developing country facing development challenges to promote the life standard of its citizens living below the poverty line. Under such condition, Nepal is facing a serious problem of research gap and dependency of foreign grants and loans. More and more inflation rate, never decreasing unemployment rate, the unacceptable amount of corruption in the financial sector, political instability, unjustified and unmanaged agriculture sector are the few examples that have been deteriorating the growth of economy.

The study tries to answer the following questions:

- What is the current implementation scenario of VAT in Nepal?

- What is the contribution of VAT on GDP, Total Revenue Total Tax Revenue and Indirect Tax Revenue?

- Do the businessmen and consumers are aware enough about VAT? 


\section{Objectives of Study}

VAT is the latest innovation in the field of taxation and is considered as the reform tax system of the 21st century, which has already been implemented popularly in more than 145 countries in the world. As the VAT is indirect tax which depends on the consumer, its implementation was not east in the initial days. It was a matter of great debate and even after its enactment; there were a loss of constraints and difficulties in introducing and implementing VAT in Nepal. But now it is well receipted by the consumers as well as business and industrial communities. VAT considered as the account based tax system as it leads to transparency and accountability on the both part of tax payers and tax collectors.

Resistance from the business community, ignorance of general people, lack of full support and commitments from the politicians and government officials has been of great hindrances in effective implementation of the VAT system.

However, specific objectives of the study are:

- To analyze the contribution of VAT to GDP, total revenue, tax revenue and indirect tax revenue.

- To explore the current status of VAT in Nepal.

- To analyze the problem faced by taxpayers on the collection and reporting system.

\section{Significance of Study}

VAT is a recent phenomenon in the arena of tax administration. VAT in Nepal has many ups and downs and twists and turn so far. Despite of all the odds, it has been able to prove itself as a strong internal revenue source. The presence of VAT has been associated with a higher ratio of general government revenue and grants to GDP. Sometimes it is argued as a particularly complex and costly tax to comply with and administer.

Internal resource mobilization should be strengthened to overcome resource gap problem. The successfully implemented of VAT has positive impact on the economy. For strengthening internal resource mobilization of Nepal, the government has already adopted VAT administration and policy, according to the reform policy and programmed noted in the eight five-year plan. This study basically concentrates on implementation structure of VAT, the importance of VAT to improve internal resource mobilization, existing problems of VAT in Nepal and provided effective suggestion to making VAT effectiveness in service sectors. In this regard, this study carries a great significance to mobilize additional resources through improved and successful implementation of VAT (Khadka, 2001).

\section{Research Design}

Research design is the plan, structure and strategy of investigation conceived so as to obtain answers to research questions and control variance. The research design refers to the 
conceptual structure within which the research is conducted. Research design describes the general plan for collecting, analyzing and evaluating data after identifying, what the researcher wants to know and what has to be dealt with in order to obtain the required information.

The research design of this study is designed as to fulfill its objectives. Both analytical and descriptive methods are used as needed for mainly primary or secondary data. Statistical tools like percentage, average, etc. are used to analyze the VAT collection and to test consumers, businessman and expert aspects. So, in one sentence the research design of this study is the combination of analytical and descriptive methods with primary and secondary data (Kothari, 1994).

\section{Population and Sample}

The population for this study was comprised of the entire person belonging to or associated with VAT in Nepal. They were Tax administrators, Experts (Lecturers, Auditors, and Lawyers), Business persons and Customers. In order to fulfill the objectives of the study, 60 samples from the population in the Kathmandu Valley were carefully selected by consultation with lecturers and best judgment of the researcher. The respondents could be divided into three groups. The following Table showed the groups of respondents and the size of samples.

Table : 1

Population and Sample

\begin{tabular}{|l|l|c|}
\hline S. No. & Group of Respondents & Sample size \\
\hline 1 & Tax administrators/experts & 20 \\
\hline 2 & Business persons & 20 \\
\hline 3 & Customers & 20 \\
\hline & Total & 60 \\
\hline
\end{tabular}

Source: Field survey, 2021

Mainly the source of data can be classified into two categories, Primary source and Secondary source. Primary data is important for all areas of research because it is unvarnished information about the results of an experiment or observation. It is like the eyewitness testimony at a trial. No one has tarnished it or spun it by adding their own opinion or bias so it can form the basis of objective conclusions. Primary data is the specific information collected by the person who is doing the research. The major tool used for the collection of primary data is questionnaire to the respondents. A set of questionnaires was developed and distributed to the selected 60 respondents so that actual result can be obtained. 


\section{Analysis and Presentation of Primary Data}

Government increased VAT rate from $10 \%$ to $13 \%$. This is done to increase the tax revenue in the national coffer. But the impact is not good enough as compared to expected. So, it is important to know whether the current rate Ok or not. If not what should be done? So the question is being asked "Is present VAT rate is appropriate?" and the obtained result is shown in the table below:

Table: 2

Appropriation of Present VAT Rate

\begin{tabular}{|c|c|c|c|c|c|}
\hline $\begin{array}{l}\text { No. of } \\
\text { Respondents(60) }\end{array}$ & $\begin{array}{l}\text { Tax Administrators/ } \\
\text { Export }\end{array}$ & Businessman & Consumer & $\begin{array}{c}\text { Total } \\
\text { Respondent }\end{array}$ & $\begin{array}{l}\% \text { of total } \\
\text { respondent }\end{array}$ \\
\hline Yes & 20 & 15 & 10 & 45 & $75 \%$ \\
\hline No & 0 & 5 & 10 & 15 & $25 \%$ \\
\hline Total & 20 & 20 & 20 & 60 & $100 \%$ \\
\hline
\end{tabular}

Source: Field survey, 2021

The above table showed the result that among the total respondent's 75\% (45 respondents) answers that the present VAT rate is appropriate while 25\% (15 respondents) says it is not appropriate. Though the Tax administrators/experts says that it is appropriate rate but the government should be very much serious while deciding the VAT rate as it should be convenience to the businessmen and consumers.

After registering the business on VAT the businessmen must follow the rules and regulations prescribed as per the rule and law. This rule and law also includes recording the transaction in the books of accounts in a prescribed manner. The books of accounts must be maintained after registering it by tax officers. For this, a question is asked to the businessmen. Books and records must be maintained for recording the transactions and the result obtained is presented in the following table:

Table: 3

Books of Accounts

\begin{tabular}{|c|l|c|c|}
\hline Respondent type & \multicolumn{1}{|c|}{ Response } & No. of respondent & Percentage \\
\hline \multirow{4}{*}{ Businessman N=20 } & Purchase book & 0 & 0 \\
\cline { 2 - 4 } & Sales book & 6 & $30 \%$ \\
\cline { 2 - 4 } & VAT account & 4 & $20 \%$ \\
\cline { 2 - 4 } & All of above & 10 & $50 \%$ \\
\hline
\end{tabular}

Source: Field Survey, 2021

From the above data, it showed that for recording the business transaction of VAT registrants, the businessmen must maintain purchase book and sales book along with VAT 
account as prescribed by the laws and rules as $50 \%$ of our respondent businessmen answered according to it while $20 \%$ replied for VAT account and $30 \%$ said that to maintained sales book.

It is found that consumers do not ask for invoices while making purchase due to afraid of increase in the price of goods and services. Everyone wants to pay less which is the nature of consumers worldwide. By not taking invoice if the goods are found cheaper then why to take bill is a common thought. In the question asked.

Table: 4

VAT Increase the Price of Commodity

\begin{tabular}{|c|c|c|c|c|c|}
\hline $\begin{array}{l}\text { No. of Respondents } \\
\text { (60) }\end{array}$ & $\begin{array}{l}\text { Tax Administrators/ } \\
\text { Export }\end{array}$ & Businessman & Consumer & $\begin{array}{c}\text { Total } \\
\text { Respondent }\end{array}$ & $\begin{array}{l}\% \text { of total } \\
\text { respondent }\end{array}$ \\
\hline Yes & 0 & 8 & 6 & 14 & $23 \%$ \\
\hline No & 20 & 12 & 4 & 36 & $60 \%$ \\
\hline I don't Know & 0 & 0 & 10 & 10 & $17 \%$ \\
\hline Total & 20 & 20 & 20 & 60 & $100 \%$ \\
\hline
\end{tabular}

Source: Field survey, 2021

Above table showed that $60 \%$ of the total respondents have negative opinion towards raising the price of commodity due to VAT where $23 \%$ of them says that price raises due to the VAT of the commodity and among them $17 \%$ replied they do not know about it.

The process of VAT registration should be easy and encouraging. Despite that, there are so many obstacles and problems during registration process and after registration. Mainly government is responsible for making the registration process simpler and to provide required information and guidance when required.

Table: 5

Problems on VAT Registration

\begin{tabular}{|c|l|c|c|}
\hline $\begin{array}{c}\text { Respondent } \\
\text { type }\end{array}$ & \multicolumn{1}{|c|}{ Response } & No. of respondent & Percentage \\
\hline \multirow{4}{*}{$\begin{array}{c}\text { Businessman } \\
\text { N=20 }\end{array}$} & The laws and rules are not clear & 8 & $40 \%$ \\
\cline { 2 - 4 } & $\begin{array}{l}\text { Don't have sufficient knowledge about VAT system } \\
\text { assistance and guideline }\end{array}$ & 3 & $15 \%$ \\
\cline { 2 - 4 } & Difficulties in following rules for VAT registrants & 2 & $10 \%$ \\
\cline { 2 - 4 } & All of above & 4 & $20 \%$ \\
\hline
\end{tabular}

Source: Field survey, 2021

The table above showed the problems faced while getting registration on VAT by the businessmen. The findings on the question asked "What are the major problems of 
registration process?" to 20 businessmen $40 \%$ said that laws and rules are not clear while $10 \%$ said the tax offices do not provide the required guidelines while $15 \%$ thinks that they don't have sufficient knowledge about VAT system and 20\% thinks that difficulties in following rules for VAT registrants and15\% of them faced all problem. Therefore, government should try to make the laws and rules simpler so as to bind the wide range of people under legal provision of VAT.

After getting any business registration on VAT they must follow the prescribed rules, act, laws and regulations related to VAT under the VAT act. So, to know more about VAT rules are the obligations that must be followed after registeringhas been asked to the tax administrators/experts and the result obtain is presented below:

Table: 6

\section{Obligations that must be followed after registration on VAT}

\begin{tabular}{|l|c|l|c|c|c|}
\hline No. of Respondents & $\begin{array}{l}\text { Tax } \\
\text { Administrators/ } \\
\text { Export }\end{array}$ & $\begin{array}{l}\text { Business } \\
\text {-man }\end{array}$ & $\begin{array}{l}\text { Consumer } \\
\text { s }\end{array}$ & $\begin{array}{c}\text { Total } \\
\text { Respondent }\end{array}$ & $\begin{array}{l}\text { \% of total } \\
\text { respondent }\end{array}$ \\
\hline $\begin{array}{l}\text { Most file VAT } \\
\text { return on or before } \\
\begin{array}{l}5^{\text {th }} \text { day following } \\
\text { the end of each } \\
\text { month }\end{array}\end{array}$ & 9 & 11 & 2 & 22 & $50 \%$ \\
\hline $\begin{array}{l}\text { Issue VAT invoice } \\
\text { on sales }\end{array}$ & 3 & 2 & 8 & 13 & $12.5 \%$ \\
\hline $\begin{array}{l}\text { Maintain books of } \\
\text { account }\end{array}$ & 2 & 2 & 6 & 10 & $10 \%$ \\
\hline $\begin{array}{l}\text { Keep VAT records } \\
\text { for a period of 6 } \\
\text { years }\end{array}$ & 1 & 1 & 1 & 3 & $5 \%$ \\
\hline All of above & 5 & 4 & 3 & 12 & $22.5 \%$ \\
\hline \multicolumn{1}{|c|}{ Total } & 20 & 20 & 20 & 60 & $100 \%$ \\
\hline
\end{tabular}

Source: Field Survey, 2021

From the data presented in the above table it can be concluded that after getting business registration on VAT the main obligation that must be followed by tax payers is to file VAT return on or before 25th day following the end of each month as $50 \%$ respondents viewed it. Similarly, $12.50 \%$ respondents have conclusion that one must issue VAT invoice after registration while $10 \%$ respondent replied for maintaining books of account and $5 \%$ replied for keeping VAT records for a period of six years and 22.5\% reply for all obligation.

VAT was introduced in Nepal to get revenue mobilization and to avoid the problems of existence tax system. As VAT is the best system to get greater revenue productivity due to the many problems relating to the implementation of the revenue collection from VAT is not 
satisfying as it has been expected. But it has generating refundable amount of revenue since it was implemented in the country. On the question asked to the respondents.

Table: 7

\section{Government Utilizing the Collected Revenue}

\begin{tabular}{|c|c|c|c|c|c|}
\hline $\begin{array}{l}\text { No. of } \\
\text { Respondents }\end{array}$ & $\begin{array}{l}\text { Tax Administrators/ } \\
\text { Export }\end{array}$ & Businessman & Consumer & $\begin{array}{c}\text { Total } \\
\text { Respondent }\end{array}$ & $\begin{array}{l}\% \text { of total } \\
\text { respondent }\end{array}$ \\
\hline Yes & 20 & 15 & 10 & 45 & $75 \%$ \\
\hline No & 0 & 5 & 5 & 10 & $17 \%$ \\
\hline I don't know & 0 & 0 & 5 & 5 & $8 \%$ \\
\hline Total & 20 & 20 & 20 & 60 & $100 \%$ \\
\hline
\end{tabular}

Source: Field survey, 2021

Table showed that most of the respondents $75 \%$ argue that revenue collection from VAT has been utilizing in a proper way while $17 \%$ believe that it has not been utilizing in a satisfactory way and $8 \%$ of them are unknown about the fact. Though $100 \%$ of Tax Administrators/ Experts say that it has been utilizing in a best possible way but only $75 \%$ of businessmen and 50\% of consumers believe that. However, 25\% of businessmen and consumers do not believe that revenue collection from VAT has been utilizing in a proper way where as $25 \%$ of consumers are unaware about the fact.

VAT was introduced on 16 Nov 1997 in Nepal. Though it is pledged that VAT has been implemented successfully in Nepal in the present context but it can't be fully considered. So, to know the present scenario of VAT implementation we have asked our respondents in a question "What is the present implementation scenario of VAT in your opinion?" and the findings are computed in the table below.

Table: 8

Implementation Scenario of VAT

\begin{tabular}{|c|c|c|c|c|c|}
\hline $\begin{array}{l}\text { No. of Respondents } \\
\text { (60) }\end{array}$ & $\begin{array}{l}\text { Tax Administrators/ } \\
\text { Export }\end{array}$ & Businessman & Consumer & Total Respondent & $\begin{array}{l}\% \text { of total } \\
\text { respondent }\end{array}$ \\
\hline Successful & 8 & 5 & 3 & 16 & $27 \%$ \\
\hline Medium & 12 & 10 & 6 & 28 & $47 \%$ \\
\hline Low & 0 & 3 & 5 & 8 & $13 \%$ \\
\hline Unsuccessful & 0 & 2 & 6 & 8 & $13 \%$ \\
\hline Total & 20 & 20 & 20 & 60 & $100 \%$ \\
\hline
\end{tabular}

Source: Field Survey, 2021

From the above table, it is found that $27 \%$ of the respondents think that VAT has been successfully implemented while $13 \%$ of them think it has unsound scenario. Similarly, $47 \%$ of respondents believe it is a medium level of implementation scenario in the present context where $13 \%$ of them answer it is in a low level of implementation in the present situation. Hence, we can say that VAT is in its good position of implementation scenario. To 
know the opinion of respondents about its current provisions, rules and regulations found the below mentioned result relating to it.

\section{Table: 9}

\section{Current Legal Provisions and Rules of VAT}

\begin{tabular}{|c|c|c|c|c|c|}
\hline $\begin{array}{l}\text { No. of Respondents } \\
(60)\end{array}$ & $\begin{array}{l}\text { Tax Administrators/ } \\
\text { Export }\end{array}$ & Businessman & Consumer & $\begin{array}{c}\text { Total } \\
\text { Respondent }\end{array}$ & $\begin{array}{l}\% \text { of total } \\
\text { respondent }\end{array}$ \\
\hline Yes & 20 & 14 & 4 & 38 & $63 \%$ \\
\hline No & 0 & 6 & 10 & 16 & $27 \%$ \\
\hline I don't know & 0 & 0 & 6 & 6 & $10 \%$ \\
\hline Total & 20 & 20 & 20 & 60 & $100 \%$ \\
\hline
\end{tabular}

Source: Field Survey, 2021

The above table displays that out of total respondents, $63 \%$ of businessmen are strongly opposing the present legal provision. It is a sad that $27 \%$ of customers are not satisfied with present legal provision of VAT, $10 \%$ of the consumers do not know about the legal provisions of tax. Though it has been trying for the successful implementation of VAT, it has to tackle and face the various difficulties and problems. So here, we have tried to find out some of the major problems in the effective implementation of VAT system in Nepal.The major problems are of present VAT system is asked to respondent and the finding is presented below:

Table: 10

\section{Major Problems of present VAT System}

\begin{tabular}{|l|c|c|c|c|c|}
\hline No. of Respondents & $\begin{array}{l}\text { Tax Administrators/ } \\
\text { Export }\end{array}$ & Businessman & Consumer & $\begin{array}{c}\text { Total } \\
\text { Respondent }\end{array}$ & $\begin{array}{l}\% \text { of total } \\
\text { respondent }\end{array}$ \\
\hline $\begin{array}{l}\text { Unawareness of } \\
\text { computer system to } \\
\text { the normal people }\end{array}$ & 4 & 3 & 5 & 12 & $20 \%$ \\
\hline $\begin{array}{l}\text { Registration } \\
\text { process }\end{array}$ & 1 & 2 & 1 & 4 & $6 \%$ \\
\hline Billing system & 5 & 3 & 4 & 12 & $20 \%$ \\
\hline Tax refund process & 3 & 4 & 6 & 13 & $22 \%$ \\
\hline All of above & 7 & 8 & 4 & 19 & $32 \%$ \\
\hline \multicolumn{1}{|c|}{ Total } & 20 & 20 & 20 & 60 & $100 \%$ \\
\hline
\end{tabular}

Source: Field Survey, 2021

The table showed that $32 \%$ respondents think that all problem face in the VAT implementation system in business sector. Out of the total respondents $20 \%$ focused on billing system. Similarly, $20 \%$ believe that it is due to the lack of awareness of sound computer system to the public while $22 \%$ says it is due to the refund process and reaming $6 \%$ of the respondent says it is due to the registration process. 
To find out the major weakness on VAT implementation and major weakness of VAT implementation to the tax administrators and experts are presented below in the following table.

Table: 11

Major Weakness of VAT Implementation

\begin{tabular}{|l|l|l|l|l|l|}
\hline $\begin{array}{l}\text { No. of } \\
\text { Respondents }\end{array}$ & $\begin{array}{l}\text { Tax } \\
\text { Administrators/ } \\
\text { Export }\end{array}$ & $\begin{array}{l}\text { Businessma } \\
\mathrm{n}\end{array}$ & $\begin{array}{l}\text { Consum } \\
\text { er }\end{array}$ & $\begin{array}{l}\text { Total } \\
\text { Responde } \\
\text { nt }\end{array}$ & $\begin{array}{l}\% \text { of total } \\
\text { respondent }\end{array}$ \\
\hline $\begin{array}{l}\text { Lack of trained } \\
\text { manpower }\end{array}$ & 2 & 5 & 13 & $22 \%$ \\
\hline $\begin{array}{l}\text { Weak } \\
\text { administration }\end{array}$ & 8 & 4 & 3 & 15 & $25 \%$ \\
\hline $\begin{array}{l}\text { Unconscious } \\
\text { taxpayer }\end{array}$ & 3 & 5 & 3 & 11 & $18 \%$ \\
\hline Weak economy & 0 & 5 & 4 & 9 & $15 \%$ \\
\hline All of above & 7 & 0 & 5 & 12 & $20 \%$ \\
\hline Total & 20 & 20 & 20 & 60 & $100 \%$ \\
\hline
\end{tabular}

Source: Field Survey, 2021

Table above showed that weak administration the major weaknesses having for the effective implementation of VAT i.e. 25\% respondents. Similarly, 20\% of them say all of the above weakness and $22 \%$ of them believe it is due to lack of trained manpower in the organization while $18 \%$ says it is due to unconscious taxpayer and $15 \%$ said that weak economy.

In order to know the most important factor for effectiveness of VAT in revenue collection in Nepal, respondents were requested to express their view about the most important factor for effectiveness of VAT in Nepal. So a question. The view of the respondents is shown in the following table:

Table: 12

Steps to be Make VAT Effective

\begin{tabular}{|l|c|c|c|c|c|}
\hline $\begin{array}{l}\text { No. of } \\
\text { Respondents(60) }\end{array}$ & $\begin{array}{l}\text { Tax } \\
\text { Administrators/ } \\
\text { Export }\end{array}$ & $\begin{array}{l}\text { Business } \\
\text {-man }\end{array}$ & Consumer & $\begin{array}{c}\text { Total } \\
\text { Respondent }\end{array}$ & $\begin{array}{l}\text { \% of total } \\
\text { respondent }\end{array}$ \\
\hline $\begin{array}{l}\text { Increase public } \\
\text { awareness }\end{array}$ & 9 & 11 & 8 & 28 & $47 \%$ \\
\hline $\begin{array}{l}\text { Develop information } \\
\text { technology }\end{array}$ & 3 & 3 & 4 & 10 & $16 \%$ \\
\hline $\begin{array}{l}\text { Improve in threshold } \\
\text { limit }\end{array}$ & 0 & 0 & 2 & 2 & $3 \%$ \\
\hline $\begin{array}{l}\text { Effective reward and } \\
\text { punishment system }\end{array}$ & 3 & 4 & 3 & 10 & $16 \%$ \\
\hline All of above & 5 & 3 & 3 & 11 & $18 \%$ \\
\hline
\end{tabular}


The above table showed that a $47 \%$ respondents want to increase public awareness programmed so that VAT can be effectively adopted and 18\% says that All of above steps to be taken while $16 \%$ believe that it can be effectively implemented by developing information technology Similarly, $16 \%$ says it can be done by providing effective reward system to the business persons so that they are motivated in the system while punishment should be given to the persons who are involved in the evasion of VAT where 3\% believe it can be made effective with the improvement in threshold limit.

In research data collection and reporting is very relevant. To collection of difference types of data and information we should have used different data collection methods.

There are two sources of VAT collection one is from Import and other is from internal sources. While importing the goods from outside country VAT is charged on the goods imported. This VAT is input tax credit for the company. The source of VAT is shown in the below diagram:

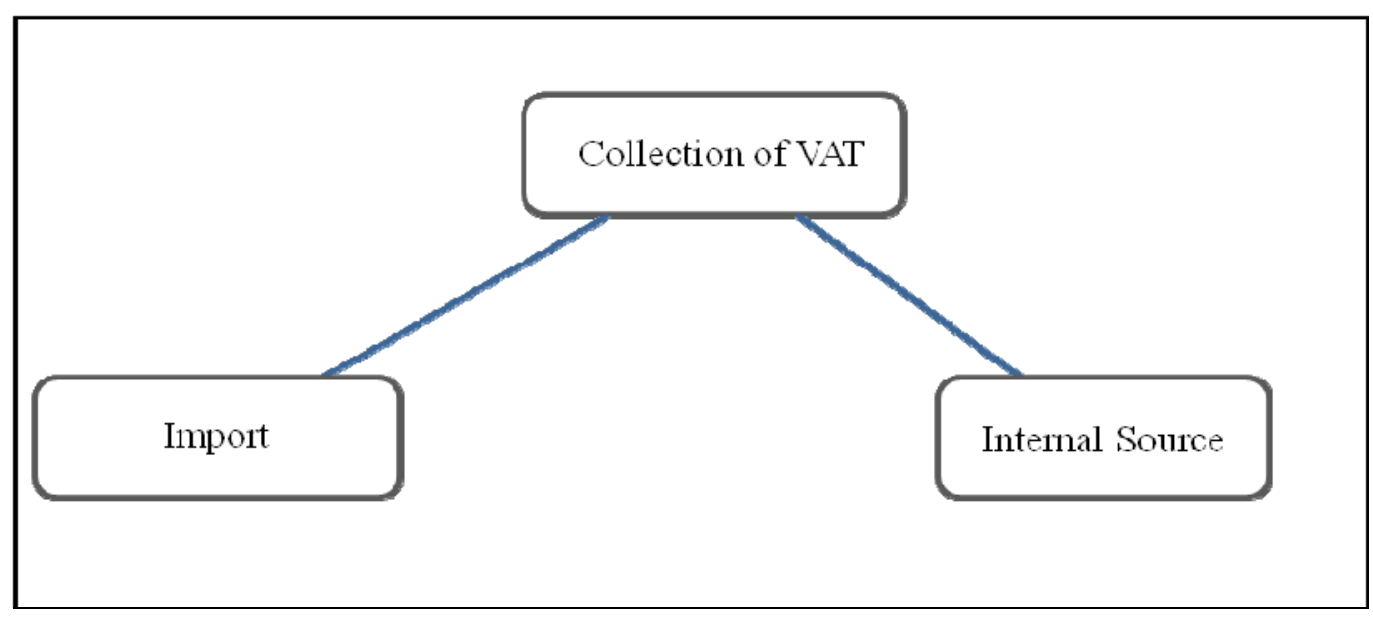

Figure: 1 Collection of VAT

In the given figure, it is shown that collection of VAT is from internal source and Import source. When the goods are reached on the Nepal border, there is a custom office where the goods are valued and accordingly VAT is charged. This import VAT is input tax credit for the company. The other is from Internal source which includes local purchases of goods and services from the VAT registered shop which is also input tax credit for the company and sales of goods and services which is Output tax credit of the company. The note should be made that only the company who are registered in VAT can deduct the output tax credit from input tax credit. If the company is not registered they cannot claim their input tax credit which they collect from purchase of goods and services. 


\section{Conclusion}

Value Added Tax (VAT) is that indirect tax which is imposed only on the value added at each stage of production and distribution of goods and services. It is the imposing of tax on sales of goods and services minus the purchase of goods. VAT as its name implies, is a tax in the value added to a commodity or service (i.e. except export and government service). Its special characteristics being that it falls on the value added at each stage from the stage of production to retail stage. It means that the value added tax is imposed on the value that business firm adds to the goods and services that purchased from other firms. It also adds value by processing or handling these purchased goods with its own labour force or machinery, building or other firms. However, value added tax belongs to the family of sales tax. A general sales tax is a tax on sales transactions but it has been applied at only one stage of the business activities. Discussing the incidence of VAT in an open economy if demand is not inelastic, there remain the possibilities of exporting some of tax to non-resident factors.

\section{References}

Adhikari, C. M. (2011). Tax laws of Nepal. Kathmandu: Pairabi Prakashan. Casanegra, M., Michele, G., \& George, E. L. (1973). The value added tax in developing countries. IMF Working Paper No. 2.

Creswell, J. W. (2009). Research Design: Qualitative, quantitative and Mix Methods Approaches (3rd ed.). University of Nebraska-Lincoln: Sage Publication.

Dangol, M. L. (2002). Resource mobilization through value added tax (VAT) in Nepal, [Unpublished MBS. Thesis]. Submitted in Shankar Dev Campus, Kathmandu.

Dhakal, K. D. (2004). Income tax administration in Nepal: Areas for reform, [Unpublished Doctoral Dissertation]. Submitted to Central Department of Management, Kathmandu.

Guerard, P. (1973). Impact of VAT in Brazilian economy, [Unpublished Doctoral Dissertation]. Submitted to Columbia University, New York. Khadka, R. B. (2001). Income Taxation in Nepal. Retrospect and Prospect. Kathmandu: Ratna Pustak Bhandar. 